\title{
Repeat Frequency Code
}

National Cancer Institute

\section{Source}

National Cancer Institute. Repeat Frequency Code. NCI Thesaurus. Code C93648.

A coded value specifying the number of occurrences of an event within a given time period. 